\title{
MOLECULAR CLONING OF PHYTASE GENE FROM ASUIA279 AND ITS EXPRESSION IN PICHIA PASTORIS SYSTEM
}

\author{
M. H. Mahamad Maifiah ${ }^{1}$, P. Jamal ${ }^{1}$, T. Nuge ${ }^{1}$, N. S. Mohd Dali ${ }^{1}$, A.S. MeOR \\ HUSSIN $^{2}$,ABD-ELAZIEM FAROUK ${ }^{3}$ AND H. MOHD. SALLEH ${ }^{1}$ \\ ${ }^{\text {I} B i o p r o c e s s ~ a n d ~ M o l e c u l a r ~ E n g i n e e r i n g ~ R e s e a r c h ~ U n i t, ~}$ \\ Department of Biotechnology Engineering, International Islamic University Malaysia, \\ Jalan Gombak, 53100 Kuala Lumpur, Malaysia. \\ ${ }^{2}$ Department of Food Technology, Faculty of Science and Food Technology, 43400, \\ University Putra Malaysia, Serdang, Selangor, Malaysia. \\ ${ }^{3}$ Department of Biotechnology, Faculty of Science, Taif University, 21974 Taif, \\ Al-Hawiayah, P. O. Box. 888, Saudi Arabia. \\ hamzah@iium.edu.my; yumi@iium.edu.my
}

ABSTRACT: Phytases catalyze the hydrolysis of phytate (myo-inositol hexakisphosphate), one of the major storage form of phosphate in plants, with subsequent release of myo-inositol, phosphate and phytate-bound minerals. Nonruminant animals such as chicken, swine and fish can't use the organic phosphorus and minerals from their diet because there is no phytase activity in their digestive tract. Phytate degrading enzyme is added to the animal feed diet to improve phosphorus availability from the dietary phytate and at the same time this lessen the phosphate pollution level in areas of intensive animal production as the phosphate would not be excreted out to the environment. ASUIA279, a bacterial strain isolated from Malaysian soil has potentially shown good phytase activity. In the present work, the gene encoding for phytase has been amplified from the plasmid DNA of recombinant ASUIA279(5) obtained from a previous study (unpublished data) by a polymerase chain reaction (PCR) methodology. The amplified phytase gene was extracted, purified then cloned into the pPICZ $\alpha A$ plasmid and transformed into Pichia pastorisX-33 strain for enzyme production.

ABSTRAK: Fitase pemangkinan hidrolisis fitat (myo-inositol hexakisphosphate), merupakan salah satu cara penyimpanan utama fosfat dalam tumbuhan, dengan pelepasan berturut myo-inositol, fosfat dan galian terikat fitat. Haiwan bukan ruminan seperti ayam, khinzir dan ikan tidak dapat memanfaatkan fosforus organik serta galian yang diperolehi daripada makanan kerana tidak mempunyai aktiviti fitase di dalam saluran pencernaan mereka. Enzim pengecilan fitase dicampurkan ke dalam pemakanan haiwan untuk mempertingkatkan keperolehan fosforus dari fitat diet. Pada masa yang sama ia dapat mengurangkan tahap pencemaran fosfat di kawasan yang terdapat penternakan haiwan secara intensif agar fosfat tidak dikumuhkan ke persekitaran. ASUIA279, satu strain bakteria yang diasingkan daripada tanih di Malaysiamenunjukkan aktiviti fitase yang memberansangkan. Buat masa kini, pengekodan gen fitase telah diperkuatkan dengan plasmid DNA dari ASUIA279(5), rekombinan yang diperolehi daripada kajian terdahulu (data tak diterbitkan) berdasarkan kaedah tindak balas berantai polimerase (polymerase chain reaction $(P C R)$ ). Gen fitase yang diperkuatkan, ditulenkan dan kemudian diklonkan menjadi plasmid pPICZ $\alpha$ A dan berubah menjadi strain Pichia pastoris $X$-33 untuk penghasilan enzim. 
KEYWORDS: phytase;animal feed;pollution;polymerase chain reaction (PCR);Pichia pastoris

\section{INTRODUCTION}

Phytic acid, phytate (myo-inositol 1,2,3,4,5,6- hexakisphosphate, $\mathrm{IP}_{6}$ ) and phytin can be referred as free acid, salt, and calcium/magnesium salt respectively [1]. The used of the terms has been used interchangeably but gives the same meaning that refer to phytate. Phytate is the major storage form for phosphorus especially in cereal grains and legumes which represents almost $75 \%$ to $80 \%$ of phosphorus in Nature [2].

Phytase is an important enzyme that functions to sequentially hydrolyze myo-inositol hexakisphosphate into less phosphorylated myo-inositol derivatives and inorganic phosphate [3]. Monogastric animals such as chicken, pig, fish as well as human do not have the ability to utilize and hydrolyze phytate into its intermediate products and phosphorus [4]. This undigested phytate together with additional inorganic phosphorus will be excreted out through their feces and this will contributes tophosphate pollution problem, eutrophication in areas of intensive livestock production [4]. In addition, phytate exhibits anti-nutritive effects as it happens to be a chelating agent and form complexes with significant multivalent metal ions mainly $\mathrm{Fe}^{2+}, \mathrm{Zn}^{2+}, \mathrm{Cu}^{2+}, \mathrm{Mg}^{2+}, \mathrm{Mn}^{2+}$ and $\mathrm{Ca}^{2+}$ which may cause mineral deficiency in animals and humans $[2,5]$.

The methylotrophic yeast, Pichia pastoris system was attributed with several important advantages over prokaryotic and other eukaryotic expression system since it has powerful and tightly regulated alcohol oxidase 1 (AOX1) promoter, performs many posttranslational modification of an eukaryotic system, for example protein folding, proteolytic processing and glycosylation [6,7]. Many works have been reported with successful overexpression of heterologous protein using the P. pastoris system [6]. Chen et al..managed to enhance phytase activity level from 118 to $204 \mathrm{U} / \mathrm{ml}$ at the flask scale and 1880-4946 U/ml for high cell-density fermentation, respectively, by appropriately modifying the medium composition and fermentation strategy of Escherichia coli phytase gene appA expressed in $P$. pastoris KM71-61 strain [8]. The genetically engineered phytase of Aspergillus niger SK-57 showed a 14.5-fold increase compared with its wild type strain produced at $6.1 \mathrm{~g} / \mathrm{l}$ of phytase or $865 \mathrm{U} / \mathrm{ml}$ phytase activity [9]. Fu et al. reported that the clone of phytase gene appA from Yersinia kristeensenii in P. pastoris GS115 exhibited specific enzymatic activity of $2656 \mathrm{Umg}^{-1}$ [10]. Furthermore, Olazaran et al., 2010 reported on the cloning and expression of native gene encoding a Bacillus subtilis phytase where the selected recombinant strain produced and secreted $0.82 \mathrm{U} / \mathrm{ml}$ of phytase activity after $48 \mathrm{~h}$ of methanol induction in shake flasks[11].

The objective of this study is to investigate the over expression pattern of phytase produced by ASUIA279 that was previously isolated from Malaysian soil[12]. The phytase encoding gene from ASUIA279 was cloned into pPICZ $\alpha$ A plasmid and expressed in P. pastoris X-33 strain.

\section{MATERIALS AND METHODS}

\subsection{Bacterial Strains, Plasmids and Chemicals}

All chemicals were analytical grade and commercially available. Recombinant ASUIA279(5) (unpublished results), One Shot TOP10 Competent cells (Invitrogen). Zero Blunt TOPO (Invitrogen) was used as cloning vector and pPICZ $\alpha$ A vector (Invitrogen) was used as expression vector, $P$. pastoris strain X-33. 


\subsection{Cloning of Phytase Gene}

Two primers were designed to cover the whole sequence of ASUIA279(5) phytase gene. The forward primer used wasESF2M (5'-GGTACCATGAAATTCAAACC-3') containing a $K p n 1$ site. A reverse primer that will remove stop codon formation at the Cterminal of the target gene sequence was designed as HSRpns1 (5'TCTAGATACAGCGGTTTA- 3') containing a xbal site.

The gene fragment encoding phytase was amplified from the recombinant plasmid ofASUIA279(5) by a polymerase chain reaction (PCR) in a master cycler gradient machine (Eppendorf) to obtain a size of $1.4 \mathrm{~kb}$ fragment and was then purified using QIAquick gel extraction kit (Qiagen). The purified DNA fragment was cloned into the Zero Blunt TOPO as cloning vector. The plasmid construct was transformed into One Shot TOP10 Competent cells. After digestion with the restriction enzyme Kpnl/Xbal, the fragment then was purified, ligated into the pPICZ $\alpha \mathrm{A}$ vector and transformed into One Shot TOP 10 according to the manufacture's protocol. The positive transformants were selected on low salt Luria-Bertani (LB) plates containing $25 \mu \mathrm{g} / \mathrm{ml}$ zeocin. The positive colony was selected for sequencing analysis.

\subsection{Linearization of Plasmid}

The positive plasmid was linearized with PmeI and purified using QIAquick gel extraction kit (Qiagen) for transformation into the expression host $P$. pastoris X-33.

\subsection{Preparation of Competent Cells}

The competent cell of $P$. pastorisX-33 was prepared according to the Pichia EasyComp. Kit (Invitrogen) manual prior to the transformation process. Single colony of $P$. pastorisX-33 strain was grown overnight in $10 \mathrm{ml}$ YPD (1\% yeast extract, $2 \%$ peptone, $2 \%$ dextrose) broth media at $30^{\circ} \mathrm{C}$ at $250 \mathrm{rpm}$. The overnight culture was diluted to an $\mathrm{OD}_{600}$ of 0.1-0.2 by addition of YPD broth media. Cells were grown at $30^{\circ} \mathrm{C}$ at $250 \mathrm{rpm}$ until the $\mathrm{OD}_{600}$ reached 1.0. The cells were then pelleted by centrifugation at $500 \mathrm{x} g$ for 5 minutes at room temperature and the supernatant was discarded. The cell pellet was resuspended in $10 \mathrm{ml}$ of solution I without further incubation and centrifuged at $500 \mathrm{x} \mathrm{g}$ for 5 minutes at room temperature. The supernatant was discarded. The cell pellet was resuspended in $1 \mathrm{ml}$ of Solution I and aliquoted of about $50 \mu \mathrm{l}$ of the prepared competent cells into labeled $1.5 \mathrm{ml}$ microcentrifuge tubes. The prepared X-33 hosts were stored in $80^{\circ} \mathrm{C}$.

\subsection{Transformation into $P$. pastoris X-33 by EasyComp Protocol}

Highly concentrated and linearized Pichia pPICZ $\alpha$ A expression plasmid (4 $\mu \mathrm{l})$ was added to the X-33 competent cells. Solution II $(1 \mathrm{ml})$ was added to the mixture and then mixed by vortexing or inverting up and down the tube. The transformation reaction was incubated for 1 hour at $30^{\circ} \mathrm{C}$ and mixed every 15 minutes by vortexing the tube. The cells were heat shocked in a $42^{\circ} \mathrm{C}$ water bath for 10 minutes. The cells were split into 2 microcentrifuge tubes ( $\sim 500 \mathrm{ul}$ per tube) and $1 \mathrm{ml}$ YPD medium was added to each tube. After incubation at $30^{\circ} \mathrm{C}$ for 1 hour, the cells were centrifuged at $3000 \times \mathrm{g}$ for 5 minutes at room temperature and the supernatant was discarded. Cells from each tube were resuspended in $500 \mu \mathrm{l}$ of solution III and the resuspended cells were combined. The tube was centrifuged at $3000 \times g$ for 5 minutes and the supernatant was discarded. The cell pellet obtained was resuspended in $120 \mu \mathrm{l}$ of solution III and plated on YPDS (1\% yeast extract, $2 \%$ peptone, $2 \%$ dextrose, $1 \mathrm{M}$ sorbitol, $2 \%$ agar) agar plate containing $50 \mu \mathrm{g} / \mathrm{ml}$ zeocin. The plate was incubated for 2 to 4 days at $30^{\circ} \mathrm{C}$. 


\subsection{Selection of High Copy Number of Multiple Integrant Phytase Strain}

The resistant zeocin colonies that grew on the plate were further selected by plating the clones on YPDS plate with incremental zeocin concentration of 100, 200, 500 and $1000 \mu \mathrm{g} / \mathrm{ml}$ of zeocin to obtain recombinant Pichia strains that possess high copy number of multiple integrants. The selected positive transformants were indicated as HSUIA279(5H)AX. Clones that survived on plate with $1000 \mu \mathrm{g} / \mathrm{ml}$ of zeocin concentration were subjected to direct PCR screening by preheating treatment of colony PCR to determine if the gene of interest has integrated into the Pichiagenome.

\subsection{Fermentation and Phytase Expression Study}

Single colony of recombinant HSUIA279(5H)AX was inoculated into $50 \mathrm{ml}$ of BMGY media (1\% Yeast extract, $2 \%$ peptone, $1.34 \%$ yeast nitrogen base (YNB), $4 \times 10^{-}$

${ }^{5} \%$ biotin, $1 \%$ glycerol, supplemented with $100 \mu \mathrm{g} / \mathrm{ml}$ of zeocin) in a $250 \mathrm{ml}$ shake flask as a starter culture for 24 hour. The starter culture (1\%) was inoculated into $100 \mathrm{ml}$ of BMGY media supplemented with $100 \mu \mathrm{g} / \mathrm{ml}$ of zeocin in a $250 \mathrm{ml}$ shake flask. The culture was grown at $30^{\circ} \mathrm{C}$ and $250 \mathrm{rpm}$ for 24 hour $\left(\mathrm{OD}_{600} \sim 1.0\right)$. The cells were centrifuged at $3000 \mathrm{x} g$ for 5 minutes at room temperature. The supernatant was decanted and the pellet was resuspended in $10 \mathrm{ml}$ BMMY media (1\% Yeast extract, 2\% Peptone, $1.34 \% \mathrm{YNB}, 4 \times 10^{-5} \%$,) to induce the expression of phytase by $1 \%$ Methanol. The culture was transferred into $100 \mathrm{ml}$ shake flask and continues to grow for 3 days. Methanol $(1 \%)$ was added to the cultures of every 24 hours to maintain the induction and $1 \mathrm{ml}$ of the cultures were collected and centrifuged at maximum speed for 3 minutes. The supernatants were collected and concentrated by a concentrator Amicon® Ultra-15. The supernatant were checked for protein expression and purity by Coomassie-stained Sodium dodecyl sulfate (SDS)-polyacrylamide gel (PAGE) 12\% electrophoresis. This step was repeated every 24 hours for four days $(24 \mathrm{hr}, 48 \mathrm{hr}, 72 \mathrm{hr}, 96 \mathrm{hr}$ ).

\subsection{Phytase Activity Assay}

Phytate-degrading activity was carried out in a total volumeof $40 \mu \mathrm{l}$ containing $25 \mu \mathrm{l}$ of $0.1 \mathrm{M}$ sodium acetate buffer, $\mathrm{pH} 4.5,10 \mu \mathrm{l}$ of $1.03 \mathrm{mM}$ sodium phytate, $\mathrm{pH} 4.5$ and $5 \mu \mathrm{l}$ of phytase sample. The assay mixture was incubated for 30 minutes at $50^{\circ} \mathrm{C}$. The liberated phosphate was measured with a slight modification of the ammonium molybdate method [13]. Freshly prepared stop solution was added into the mixture that basically contains acetone: $5 \mathrm{~N}$ sulphuric acid $\left(\mathrm{H}_{2} \mathrm{SO}_{4}\right): 10 \mathrm{mM}$ ammonium molybdate $(2: 1: 1 \mathrm{v} / \mathrm{v})$ and $10 \mu \mathrm{l}$ citric acid. The control was prepared by adding the stop solution prior to adding the enzyme into the assay mixture. The phytase activity was calculated from the average of at least three phytase assay measurements.

$$
\text { Phytase activity }(\mathrm{Unit} / \mathrm{ml})=\frac{\text { OD uf vulume tul:al }}{\mathrm{t}, \mathrm{D} \cdot \varepsilon \cdot \text { Volume of enzy }}(1)
$$

where OD of volume total, differences in OD reading of volume total; t, time of incubation (min); D, thickness of the microplate reader $(0.59 \mathrm{~cm})$; $\square$, extinction coefficient $(0.3094$ $\mu \mathrm{mol} / \mathrm{ml} . \mathrm{cm})$.

\section{RESULTS AND DISCUSSION}

The plasmid, ASUIA279(5) was amplified by PCR using designed primers with deletion of stop codon at the $\mathrm{C}$ terminus of the expressed protein to allow binding of the 
secreted protein during the purification stage. The amplified fragment was successfully purified and cloned into pCRII-Blunt-TOPO cloning vector. Highly concentrated, digested and purified plasmid was ligated into the pPICZ $\alpha \mathrm{A}$ expression vector and transformed into TOP 10 E. coli plated on low salt LB with $25 \mu \mathrm{g} / \mathrm{ml}$ zeocin. One positive colony was selected from the plate after being confirmed by restriction enzyme digestion with Kpnl and Xbal. The amino acids sequence revealed 99\% homology with the referred sequence of ASUIA279 (5) (unpublished) with polyhistidine tag sequence at the $\mathrm{C}$ terminal (Fig. 1).

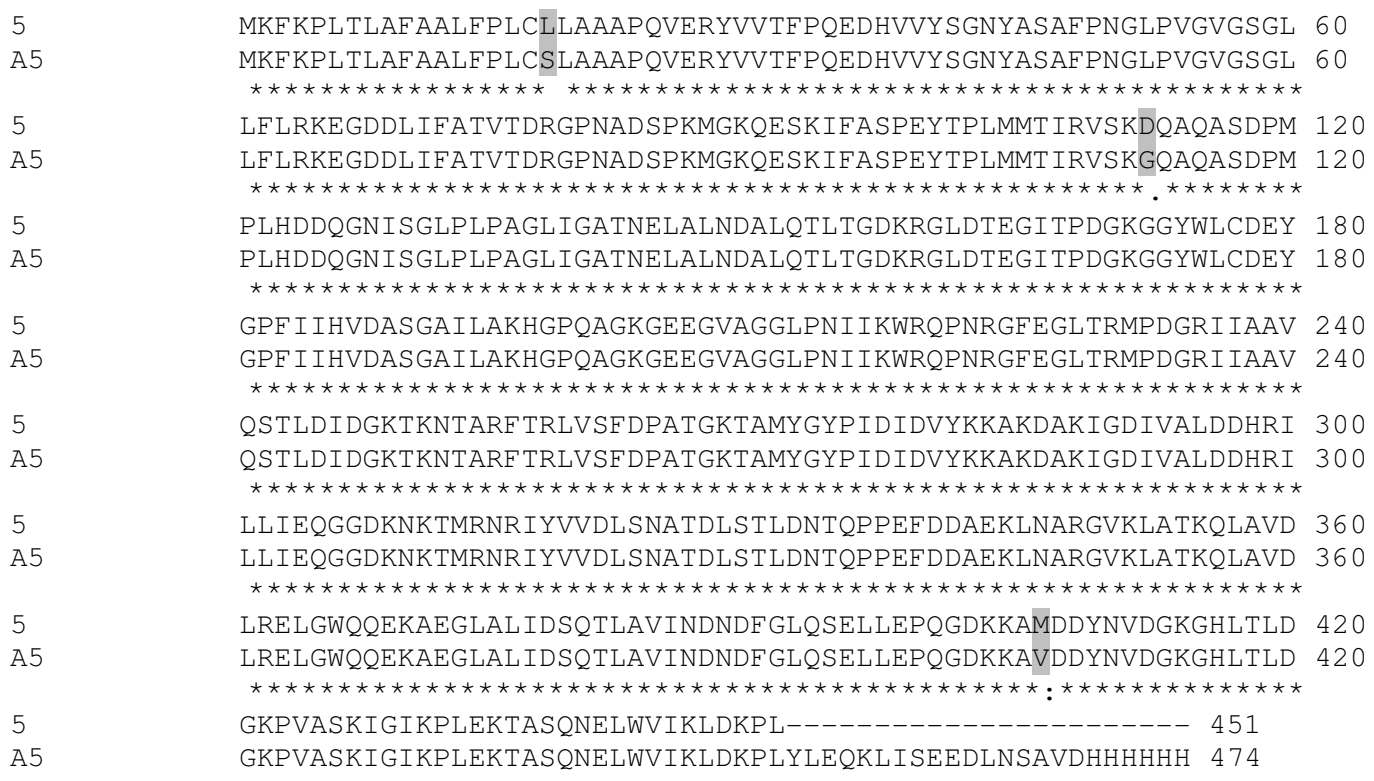

Fig 1: Comparison of amino acid sequences between HSUIA279(5H)A gene and the ASUIA279(5) gene. The expected size of phytase gene without addition of

His-tag is $48.71 \mathrm{kDa}$ while with the addition of $\mathrm{His}_{6 \mathrm{x}}$-tag is $51.48 \mathrm{kDa}$ after calculated from primary structure analysis of ExPASy proteomics server.

The plasmid was linearized by Pme1 to effectively integrate the gene into the AOX1 locus of the P. pastoris genome. The purified plasmid was transformed into X-33 Pichia strain by EasyComp method and plated on YPD agar with $25 \mu \mathrm{g} / \mathrm{ml}$ zeocin. Transformants that grew on the plate were picked and replated on $100 \mu \mathrm{g} / \mathrm{ml}, 500 \mu \mathrm{g} / \mathrm{ml}$, and $1000 \mu \mathrm{g} / \mathrm{ml}$ zeocin successively. The results showed that the transformants contain multicopy numbers of expression cassettes in the genome as they grew on high concentration of zeocin(Fig. 2). The existence of the expression cassettes in their genome will lead to over expression of high concentration of heterologous phytase [14]. In addition, the integration process of the vector will increase the stability of the expression recombinant [15]. Ten of the transformants were subjected to colony PCR in order to verify the presence of the phytase gene and its integration into $P$. pastoris genome. The result shows that there are two bands after done the colony PCR reaction (Fig. 3). A $\sim 2.2 \mathrm{~kb}$ band size appeared to be the AOX1 gene of $P$. pastoris strain using the AOX1 primers while a $\sim 1.9 \mathrm{~kb}$ band size represents the HSUIA279(5H)AX phytase gene. 


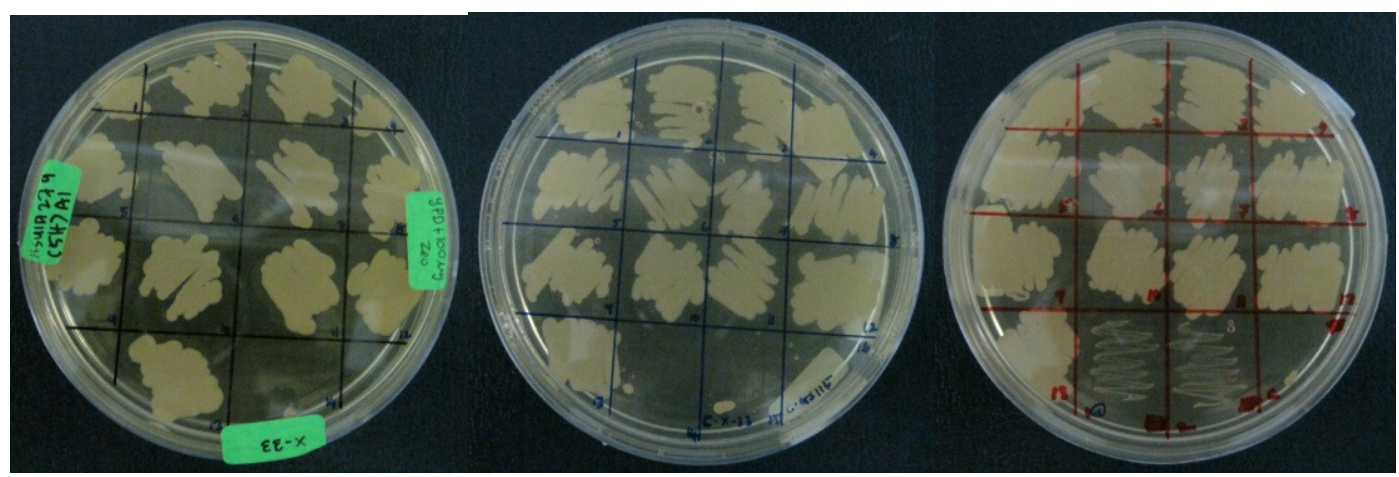

Fig. 2: Growth of zeocin resistant $P$. pastoris X-33 transformants on YPD plate with zeocin concentration of (a) $100 \mu \mathrm{g} / \mathrm{ml}$ zeocin, (b) $200 \mu \mathrm{g} / \mathrm{ml}$ zeocin and (c) $1000 \mu \mathrm{g} / \mathrm{ml}$ zeocin after 2 days of incubation period respectively.

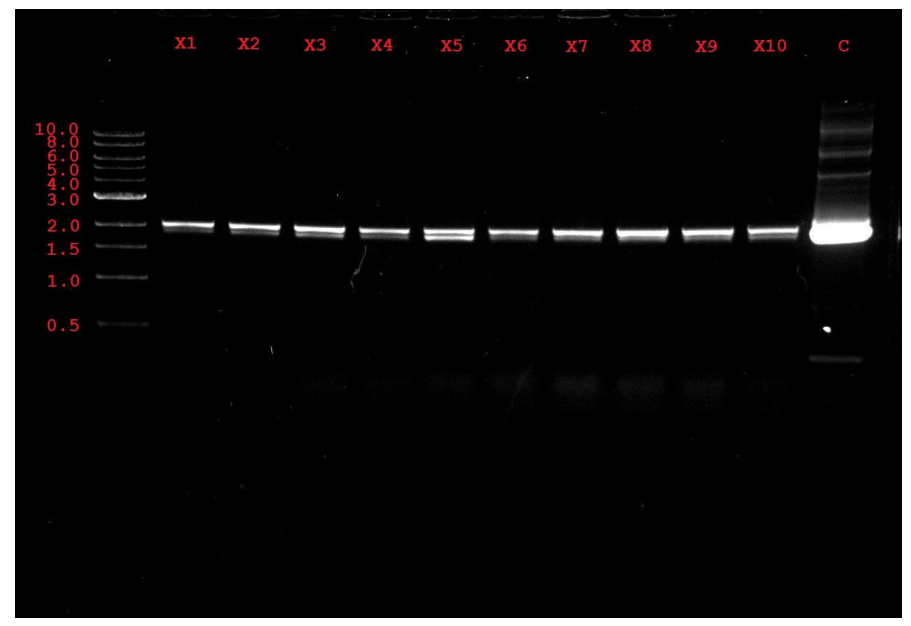

Fig. 3: Colony PCR of clone 1 to 10 . Two bands represent the transformant's phytase gene $(1.9 \mathrm{~kb})$ and AOX1 gene $(2.2 \mathrm{~kb})$ of $P$. pastoris strain using the AOX1 primers. $\mathrm{C}$ indicatescontrol which is plasmid clone before it was transformed into PichiaX-33 strains.

Recombinant phytase, HSUIA279(5H)AX was expressed in P.pastoris X-33 strain as secreted protein after fermentation in medium BMGY and BMMY in shake flask cultures after methanol induction. Culture supernatants collected after $24 \mathrm{hrs}, 48 \mathrm{hrs}, 72 \mathrm{hrs}$ and 96 hrs were concentrated by a concentrator Amicon ${ }^{\circledR}$ Ultra-15 and then analyzed on SDSPAGE (Fig. 4). Phytase was successfully expressed and detected from the recombinant HSUIA279 $(5 \mathrm{H}) \mathrm{AX}$ culture supernatant at 24 hours interval during 4 days fermentation while no protein was observed from the wild type of $P$. pastoris $\mathrm{X}-33$ strain.

Phytase expression was increasingly enhanced from day 1 till day 4 . The highest extracellular phytase expression occurred after $96 \mathrm{hrs}$ fermentation period. The secreted recombinant phytase detected on SDS-PAGE show apparent molecular weight of $55 \mathrm{kDa}$ which was slightly greater than the predicted size of primary sequence $(51 \mathrm{kDa})$. This is probably the result of glycosylation that normally occurs in protein translational modification for yeast secreted proteins. 


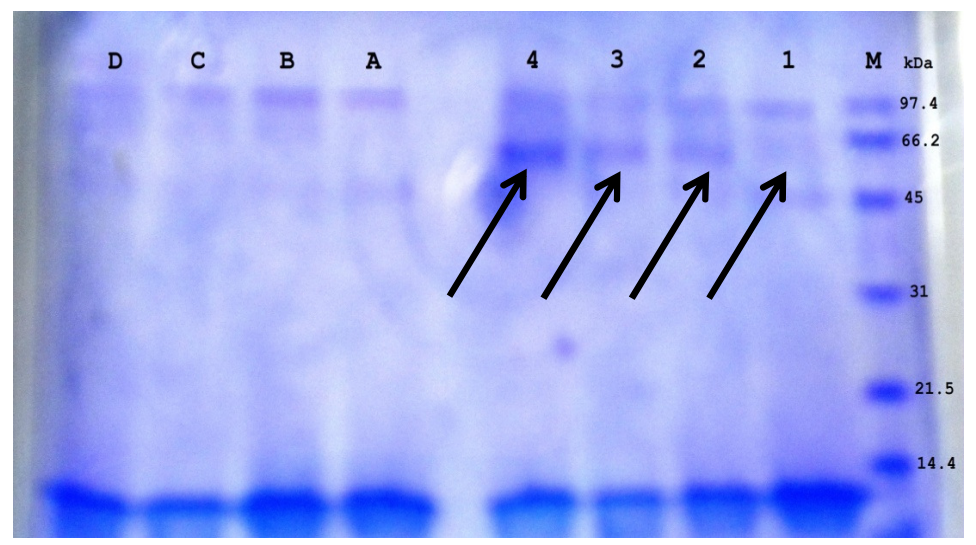

Fig. 4: SDS-PAGE analysis of the expressed crude phytase enzyme. Lane 1-4 is phytase expression after $24,48,72$ and 96 hour induction respectively with $0.5 \%$ methanol induction. Lane A-D represents control study which is wild type X-33 at the same conditions after 24, 48, 72 and 96 hour induction with $0.5 \%$ methanol.

The recombinant clone gave activity of $17.004 \mathrm{U} / \mathrm{ml}$ after 48 hours of incubation period under the current growth conditions. $P$. pastoris would secrete very little amount of native proteins, while secrete the huge amount of heterologous protein of interest [16]. This would be an advantage for protein recovery and purification processes.

\section{CONCLUSION}

The cloning of the phytase enzyme from ASUIA279 into the $P$. pastoris system would be a significant consideration for a cost effective measure to produce a high yield and activity enzyme for animal feed application.

\section{ACKNOWLEDGEMENTS}

This research work is funded by Biotech Research Project from the Ministry of Science, Technology and Innovation (MOSTI) Malaysia, (grant project no. 07-01-08-EIB011). The authors also thanked Dr. Farah Diba Abu Bakar for valuable discussions.

\section{REFERENCES}

[1] R. Angel, N.M. Tamim, T. J. Applegate,A. S. Dhandu, L. E. Ellestad. "Phytic Acid Chemistry: Influence on Phytin-Phosphorus Availability and Phytase Efficacy". J. Appl. Poult. Res. 11:471-480, 2002.

[2] B.C. Oh, W.C. Choi,S. Park,Y.O. Kim,T.K. Oh. "Biochemical properties and substrate specificities of alkaline and histidine acid phytases". Appl Microbiol Biotechnol 63: 362372, 2004.

[3] X. Wang,S. Upatham,W. Panbangred,D. Isarangkul,P. Summpunn,S. Wiyakrutta,V. Meevootisomd. "Purification, Characterization, Gene Cloning and Sequence Analysis of a Phytase from Klebsiella pneumoniae subsp. pneumoniae XY-5”.ScienceAsia30: 383-390, 2004.

[4] J. Dvorakova "Phytase: sources, preparation and exploitation- review". Folia microbiol. 43 (4), 323-338, 1998. 
[5] S. Haefner,A. Knietsch,E. Scholten,J. Braun, M. Lohscheidt,O. Zelder. "Biotechnological production and applications of phytases".Appl Microbiol Biotechnol 68: 588-597, 2005.

[6] G.P.L. Cereghino,J.L. Cereghino,C. Ilgen, J.M. Cregg. "Production of recombinant proteins in fermenter cultures of theyeast Pichiapastoris".Current Opinion in Biotechnology, 13:329-332, 2002.

[7] A.L. Zhang,J.X. Luo,T.Y. Zhang,Y.W. Pan, Y.H. Tan,C.Y. Fu,F.Z. Tu. "Recent advances on the GAP promoter derived expression system of Pichia pastoris". Mol Biol Rep 36:1611-1619, 2009.

[8] C.C. Chen,P.H. Wu,C.T. Huang,K.J. Cheng. "A Pichia pastoris fermentation strategy for enhancing the heterologous expression of an Escherichia coli phytase". Enzyme and Microbial Technology. 35, 315-320, 2004.

[9] A.S. Xiong,Q.H. Yao,R.H. Peng,P.L. Han,Z.M. Cheng,Y. Li."High level expression of a recombinant acid phytase gene in Pichia pastoris".Journal of Applied Microbiology, 98: 418-428, 2005.

[10] D.Fu,H. Huang,H. Luo,Y. Wang,P. Yang, K. Meng,Y. Bai,N. Wu,B. Yao.“A highly pHstable phytase from Yersinia kristeensenii: Cloning,expression, and characterization". Enzyme and Microbial Technology, 42: 499-505, 2008.

[11] M.G. Olazara’n,L.R. Blanco,J.G.C. Treviño,J.A.G. Lo'pez, J.M.V. Salvado."Expression of a Bacillus Phytase C Gene in Pichia pastoris and Properties of the Recombinant Enzyme". Applied and Environmental Microbiology. 5601-5608, 2010.

[12] Anis Shobirin, M. H., Farouk, A., Greiner, R., Salleh, H. M. and Ismail, A. F. "Phytatedegrading enzymes production by Malaysian soil bacteria". World Journal of Microbiology and Biotechnology 23, 1653-1660, 2007.

[13] J.K. Heinonen, and R.J. Lahti "A new and convenient colorimetric determination of inorganic orthophosphate and its application to the assay of inorganic pyrophosphatase". Anal Biochem 113:313-317, 1981.

[14] N.T. Xuan,M.T. Hang,V.N. Thanh. "Cloning and over Expression of an Aspergillus niger XP Phytase Gene (phyA) in Pichia pastoris". World Academy of Science, Engineering and Technology 56, 2009.

[15] J.L. Cereghino andJ.M. Cregg"Heterologous protein expression in the methylotrophic yeast Pichia pastoris". FEMS Microbiology Reviews 24: 45-66, 2000.

[16] Y. Bin,Z. Chunyi,W. Jianhua,F. Yunliu. "Recombinant Pichia pastoris overexpressing bioactive phytase".Science in China (Series C). Vol. 41: No. 3, 1998. 